This is the peer reviewed version of the following article: Z. Anorg. Allg . Chem. 2018, 644,1705-1710, which has been published in final form at: https://doi.org/10.1002/zaac.201700350

ARTICLE

DOI: $\mathbf{1 0 . 1 0 0 2 / z a a c . 2 0 0 ( ( w i l l ~ b e ~ f i l l e d ~ i n ~ b y ~ t h e ~ e d i t o r i a l ~ s t a f f ) ) ~}$

\title{
Synthesis and X-ray crystal structures of homotrimetallic Zinc Bisureate Complexes
}

\author{
Melike Bayram, Christoph Wölper and Stephan Schulz*
}

Keywords: bis(ureate), zinc, single crystal

Alkane elimination reactions of the tethered bis(urea) proligand 1,4- $(t-\mathrm{BuNHCONH})_{2}-\mathrm{C}_{4} \mathrm{H}_{8} 1$ with $\mathrm{ZnR}_{2}(\mathrm{R}=\mathrm{Me}, \mathrm{Et}, n-\mathrm{Pr})$ yielded trimetallic zinc complexes $\left[\mathrm{RZn}-1,4-(t-\mathrm{BuNHCON})_{2}-\mathrm{C}_{4} \mathrm{H}_{8}\right]_{2} \mathrm{Zn}(\mathrm{R}$

$=$ Me 2, Et 3, $n$-Pr 4). 2 - 4 were characterized by heteronuclear NMR $\left({ }^{1} \mathrm{H},{ }^{13} \mathrm{C}\right)$ and IR spectroscopy, elemental analysis and single crystal X-ray diffraction.

\footnotetext{
* Prof. Dr. Stephan Schulz

Fax: + 49 0201-1834635, Phone: + 4902011834635 stephan.schulz@uni-due.de

Faculty of Chemistry and Center for Nanointegration Duisburg-Essen (Cenide), University of Duisburg-Essen, 45117 Essen, Germany

E-mail: Homepage: http://www.uni-due.de/ak_schulz/ Supporting information for this article is available on the Đ WWW under http://dx.doi.org/10.1002/zaac.201000xxx or from the author.
}

\section{Introduction}

Transition metal and main group metal complexes containing monoanionic $\mathrm{N}, \mathrm{N}$-chelating substituents such as $\beta$-diketiminates I, amidinates II and guanidinates III have been synthesized and structurally characterized in large number. Surprisingly, their N,O-chelating counterparts ketiminates IV, amidates $\mathbf{V}$ and ureates VI - have been substantially less investigated. ${ }^{[1]}$<smiles></smiles>

IV

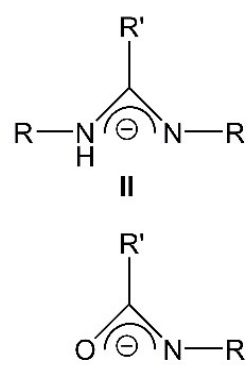

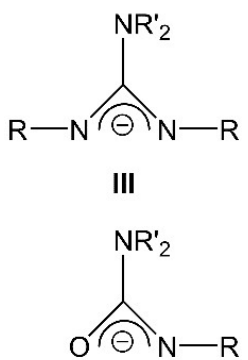

$\mathrm{VI}$
R, R' = H, alkyl, aryl, $\mathrm{SiMe}_{3}$

Scheme 1. N,N'- and N,O-chelating substituents.

Urea $\mathrm{H}_{2} \mathrm{NC}(\mathrm{O}) \mathrm{NH}_{2}$, also known as carbamide or carbonyldiamide, whose synthesis by Wöhler represents the birth of organic chemistry, ${ }^{[2]}$ and its organic derivatives such as tetramethylurea have been widely used as neutral ligand in coordination chemistry. A large number of complexes of different main group metals, transition metals and lanthanides have been synthesized and structurally characterized. $^{[3]}$ Metal urea complexes find different applications and are typically used as fertilizers ${ }^{[4]}$ and in pharmaceutical application, e.g. a platinum-urea complex is an antitumor reagent. ${ }^{[5]}$ In addition, urea-based receptors are used for anion recognition due to their capability to form hydrogen-bonding interactions with a large number of different anions. ${ }^{[6]}$ Recently, oligoureas have received increasing interest due to their capability to serve as a helical platform for the fabrication of nanostructures in aqueous conditions. ${ }^{[7]}$

Neutral urea typically serves as monodentate ligand and coordinates to the metal center by its oxygen atom (A), while the N,O-bidentated (B) and O-bridging coordination modes (C), which is observed in complexes with monovalent cations, ${ }^{[8, d]}$ are less common. ${ }^{[8]}$ Comparable findings were made for $\mathrm{N}, \mathrm{N}^{\prime}$-dimethylurea $\mathrm{OC}(\mathrm{NHMe})_{2}$ and $\mathrm{N}, \mathrm{N}$ '-tetramethylurea $\mathrm{OC}\left(\mathrm{NMe}_{2}\right)_{2} \cdot{ }^{[9]} 27$ hits were found in the Cambridge structural database for N,N'-dimethylurea $\mathrm{OC}(\mathrm{NHMe})_{2}$ complexes and 48 hits for N,N'tetramethylurea $\mathrm{OC}\left(\mathrm{NMe}_{2}\right)_{2}$ complexes. The urea ligands in these complexes exclusively bind in a monodentate coordination mode through the carbonyl oxygen atom $(\mathbf{A})$.

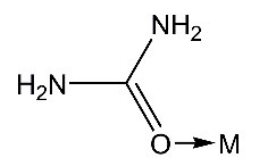

A

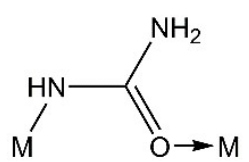

D<smiles>[M]OC(N)=[W]</smiles>

B<smiles></smiles>

E<smiles>[M]OC(N)=[W]</smiles>

C<smiles></smiles>

$\mathbf{F}$
Scheme 2. Binding modes observed in urea and ureate complexes.

In contrast, the number of complexes containing its deprotonated, monoanionic ureate ligand is significantly 
lower. These complexes, which are of particular interest in bioinorganic chemistry, were obtained by metal-promoted deprotonation reactions and the resulting monoanionic ureate ligand was found to adopt $\mu_{2}-\kappa \mathrm{N}: \kappa \mathrm{O}-(\mathbf{D})$ and $\mu_{3}-$ $\kappa \mathrm{N}: \kappa \mathrm{N}$ : $\kappa \mathrm{O}$-bridging (E) as well as $\kappa^{2}-\mathrm{N}, \mathrm{O}$-chelating $(\mathbf{F})$ coordination modes. ${ }^{[10]}$ Moreover, metalation reactions of urea with alkali metal $(\mathrm{Na}-\mathrm{Cs})$ in liquid ammonia at temperatures below $50{ }^{\circ} \mathrm{C}$ yielded the corresponding alkali metal ureate complexes, ${ }^{[11]}$ whereas alkane elimination reactions of group 4 metal tetraalkyls with alkylated ureas gave the corresponding group 4 metal ureates. ${ }^{[12]}$ Compared to sterically analogous amidates, ureates are electron-rich ligands due to the electron-donating amino group attached to the central carbon atom. Therefore, the stabilization of such highly electropositive group 4 metals is reasonable.

In addition to as-described urea and ureate complexes, transition metal complexes of bis(ureas) ${ }^{[13]}$ and of tethered bis(ureates) ${ }^{[14]}$ have been reported. Compared to untethered bis(ureate) complexes, complexes containing tethered ligands often exhibit less fluxional behavior and coordination isomerism is also often suppressed. ${ }^{[10 \mathrm{~d}]}$ Moreover, the steric accessibility of the metal center is typically increased by enforcing an equatorial disposition of the ligand As a consequence, such complexes are of potential interest in catalysis and indeed, tethered bis(ureate) zirconium complexes showed an unprecedented reactivity in the intermolecular hydroamination of alkynes and the intramolecular hydroamination of alkenes. The catalytic activity of the alkyl-tethered bis(ureate) zirconium complex $\mathrm{H}\left(\mathrm{Me}_{2}\right) \mathrm{NZr}\left(\mathrm{NMe}_{2}\right)_{2}-\left[\mu-1,3-\left(\mathrm{NC}\left(\mathrm{N} i-\mathrm{Pr}_{2}\right) \mathrm{O}\right)_{2} \mathrm{CH}_{2} \mathrm{CMe}_{2} \mathrm{CH}_{2}\right]$ was found to be significantly enhanced compared to untethered bis(ureate) complexes. ${ }^{[14 b, 15]}$ In addition, tethered bisureate ligands are of general interest since they in principle may give access to bimetallic complexes. Homoand heterobimetallic complexes have received steadily increasing interest in recent years since the presence of two metal centers is a pre-requisite for possible beneficial cooperative effects. ${ }^{[16]}$

We are generally interested in the synthesis and solid state structures of homo- and heteroleptic zinc complexes containing $\mathrm{N}, \mathrm{N}^{\prime}$-chelating $\beta$-diketiminates ${ }^{[17]}$ and amidinates, ${ }^{[18]}$ as well as of $\mathrm{N}, \mathrm{O}$-chelating ketoiminates ${ }^{[19]}$ and their potential capability to serve as catalyst in the ROP of rac-lactide ${ }^{[20]}$ Moreover, we recently reported on the synthesis and solid state structures of tethered bisamidinate alane complexes. ${ }^{[21]}$ These studies prompted our interest towards tethered bis(ureate) complexes and we herein report on reactions of the bis(urea) $1,4-(t-\mathrm{BuNHCONH})_{2}-\mathrm{C}_{4} \mathrm{H}_{8} \mathbf{1}$ with three zinc dialkyls $\mathrm{ZnR}_{2}$, yielding homotrimetallic zinc bis(ureate) complexes of the general type [RZn-1,4-( $t$ BuNHCON $\left.)_{2}-\mathrm{C}_{4} \mathrm{H}_{8}\right]_{2} \mathrm{Zn}(\mathrm{R}=\mathrm{Me} 2$, Et 3, $n$-Pr 4). To the best of our knowledge, compounds $\mathbf{2 - 4}$ represent the first zinc complexes containing tethered bisureate ligands. The solidstate structures of 1-4 were determined by single crystal Xray diffraction.

\section{Results and Discussion}

The starting tethered bis(urea) ligand 1.4- $(t$ BuNHCONH$]_{2}-\mathrm{C}_{4} \mathrm{H}_{8} \quad 1$ was synthesized according to literature method and identified by $\operatorname{NMR}\left({ }^{1} \mathrm{H},{ }^{13} \mathrm{C}\right)$ and IR spectroscopy. ${ }^{[22]}$ Single crystals of $\mathbf{1}$ were obtained upon storage of a solution in $\mathrm{CHCl}_{3}$ at $-30{ }^{\circ} \mathrm{C}$ after $12 \mathrm{~h}$.

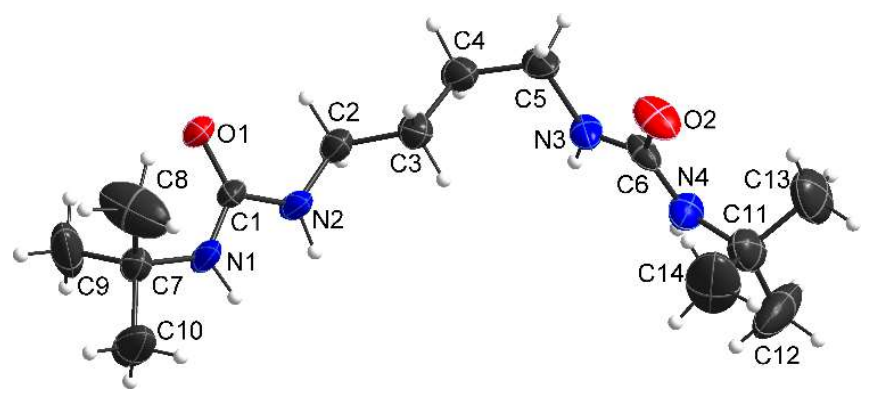

Figure 1. Solid state structure of 1. Non-H-atoms shown as thermal ellipsoids at $50 \%$ probability levels, $\mathrm{H}$ atoms as spheres of arbitrary radii. Only one of the three independent molecules is displayed.

1 crystallizes in the hexagonal space group $P 6_{1}$ with three independent molecules in the asymmetric unit, of which one is partially disordered over two positions. The overall quality of the diffraction data was limited and the hydrogen atoms couldn't be identified in the difference Fourier synthesis. However, the resulting model gives a reliable connectivity and the resulting quantitative results are reasonable. The $\mathrm{C}-\mathrm{C}$ bond lengths and bond angles are typical for $\mathrm{sp}^{3}$ hybridized carbon atoms. The N1-C7

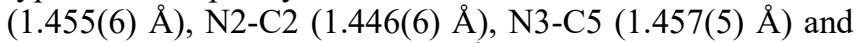
N4-C11 bond lengths $(1.475(6) \AA)$ are also typical for N-C single bonds, whereas the N1-C1 (1.351(6) $\AA$ ), N2-C1 $(1.352(5) \AA)$, N3-C6 (1.338(5) $\AA)$ and N4-C6 bonds (1.346(5) $\AA$ ) are significantly shorter. The C1-O1 (1.236(4) $\AA$ ) and C6-O2 bond length (1.237(4) $\AA$ ) are in the range of $\mathrm{C}=\mathrm{O}$ double bonds. $\mathrm{C} 1$ and $\mathrm{C} 6$ adopt trigonal-planar coordination spheres [sum of bond angles $359.9^{\circ}(\mathrm{C} 1), 360^{\circ}$ (C6)], which allow a delocalization of the $\pi$-electron density within the $\mathrm{CON}_{2}$ units, resulting in multiple bonding character. These values correspond very well with those reported for urea, which show comparable C-O $(1.26 \pm 0.01$ $\AA)$ and $\mathrm{C}-\mathrm{N}(1.34 \pm 0.01 \AA)$ bond lengths. ${ }^{[23]}$ Based on calculated and observed bond lengths for urea, the double bond character of the carbon-nitrogen bond was estimated to about $20-30 \%$, while that of the carbon-oxygen bond was estimated to $50-60 \%{ }^{[3 e, 24]}$ The Cambridge structural database shows 566 hits for compounds containing a urea unit of the type $\mathrm{X}_{3} \mathrm{CNHCONHCX}_{3}$ (X = "any atom"), showing comparable average $\mathrm{C}-\mathrm{N}$ (mean value $1.354 \pm$ $0.015 \AA$ ) and $\mathrm{C}-\mathrm{O}$ bond lengths (mean value $1.242 \pm 0.014$ $\AA) .{ }^{[9]}$

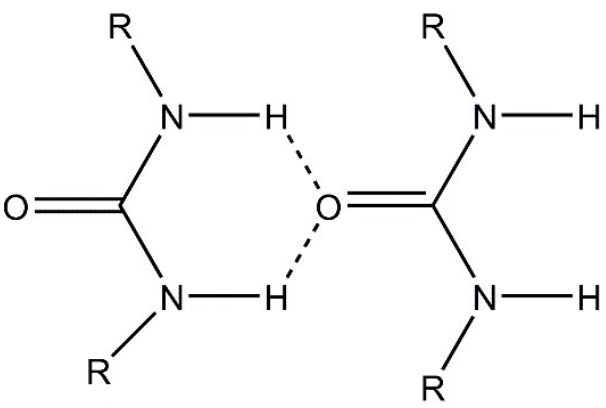

Scheme 3. $\mathrm{R}_{2}{ }_{2}(6)$ Interaction motif in RHNCONHR residues (approx. 800 hits in the CSD). 
The bond length and angle of the other independent molecules of $\mathbf{1}$ are comparable and can be found in the SI. The model suggests that the packing is dominated by the $\mathrm{R}_{2}^{1}{ }_{2}(6)$ motif of hydrogen bonds commonly found in RHNCONHR (see Scheme 3). Strings of these motifs along $<210>$ appear to be present. However, considering the limited quality of the model, we do not consider it appropriate to discuss the packing in further detail.

The general synthesis of the zinc complexes is shown in Scheme 4. 2-4 were obtained from reactions of 1 with the corresponding zinc dialkyl $\mathrm{ZnR}_{2}(\mathrm{R}=\mathrm{Me}, \mathrm{Et}, n-\mathrm{Pr})$ in $2: 3$ molar ratio. Reactions with $1: 1$ and $1: 2$ molar ratio also exclusively yielded 2-4 in addition to non-reacted $\mathbf{1}$ and $\mathrm{ZnR}_{2}$, respectively. In addition, analogous reactions at $80^{\circ} \mathrm{C}$ also proceeded only with formation of $\mathbf{2 - 4}$, proving the thermal stability of these compounds in solution.
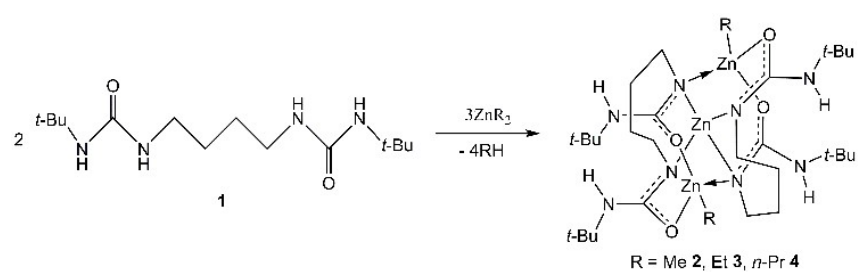

Scheme 4. Synthesis of $\mathbf{2}-\mathbf{4}$.

2-4 are soluble in common organic solvents such as toluene and THF. ${ }^{1} \mathrm{H}$ and ${ }^{13} \mathrm{C}$ NMR spectra of $2-4$ in noncoordinating $\left(\mathrm{C}_{6} \mathrm{D}_{6}\right)$ and coordinating solvents $\left(\mathrm{THF}-\mathrm{d}_{8}\right)$ are comparable, each showing the expected resonances due to the $t$ - $\mathrm{Bu}$ groups and the $\mathrm{C}_{4} \mathrm{H}_{4}$ bridging unit of the ureate ligand as well as the alkyl group bonded to the $\mathrm{Zn}$ atom $(\mathrm{R}=$ Me 2, Et 3, n-Pr 4) in a 2:3 molar ratio. These findings doesn't surprise since we did not expect any coordination of the solvent molecule (thf) to the zinc atoms, which adopts tertrahedral coordination spheres. In addition, each ${ }^{1} \mathrm{H}$ NMR spectra also exhibits two additional resonances of equal intensity for the remaining $\mathrm{N}-\mathrm{H}$ groups at $\delta_{\mathrm{H}} 3.8$ and 4.7 , respectively. Temperature-dependent ${ }^{1} \mathrm{H}$ NMR spectroscopy studies gave no indication for any type of dynamic properties of 2-4, since only some line broadening at lower temperatures $\left(-80^{\circ} \mathrm{C}\right)$ was observed. We therefore believe that 2-4 adopt the same structures as observed in the solid state. The NMR spectroscopy findings were confirmed by IR spectroscopy. The IR spectra of 2-4 each display rather broad absorption bands due to the symmetric and asymmetric stretching vibrations of the remaining $\mathrm{N}-\mathrm{H}$ groups. The carbonyl stretching vibrations are found at 1558 $\mathrm{cm}^{-1}$ (2), $1580 \mathrm{~cm}^{-1}$ (3) and $1582 \mathrm{~cm}^{-1}$ (4), respectively, which are shifted to lower frequecies compared to those observed for $1\left(1638 \mathrm{~cm}^{-1}\right)$. The stretching frequency of the carbonyl vibration of urea $\left(\mathrm{NH}_{2}\right)_{2} \mathrm{CO}$ is at $1686 \mathrm{~cm}^{-1}$, which is shifted to a lower frequency number compared to that observed for acetone $\left(1715 \mathrm{~cm}^{-1}\right)$, which contains a "true" $\mathrm{C}=\mathrm{O}$ double bond. This shift is caused by the delocalization of the $\pi$ electron density within the $\mathrm{N}_{2} \mathrm{CO}$ core, resulting in a reduction of the double bond character to roughly $60 \%$.

Single crystals of 2-4 were obtained upon storage of solutions in fluorobenzene/ $\mathrm{Et}_{2} \mathrm{O}$ at $-30{ }^{\circ} \mathrm{C}$ after 5 days (2) or in toluene/ $\mathrm{Et}_{2} \mathrm{O}$ at $0{ }^{\circ} \mathrm{C}$ after $24 \mathrm{~h}(\mathbf{3}, 4) .2$ crystallizes in the monoclinic space group $P 2 / n$ with the molecules placed on the two-fold axis. $\mathbf{3}$ is possibly isostructural to $\mathbf{2}$, but the best model available uses the triclinic space group $P-1$ with one molecule in the asymmetric unit. Though quantitative results of this model should be taken with care, the connectivity is reliable. 4 crystallizes in the monoclinic space group $P 2_{1} / c$ with the molecules placed on the general position.

The solid state structures of $\mathbf{2}-\mathbf{4}$ are very similar. The four monoanionic ureate units serve as $\mu_{2}-\kappa N$ : $\kappa O$ bridging units between the central zinc atom $(\mathrm{Zn} 1)$ and one of the outer $\mathrm{Zn}$ atoms $\left(\mathrm{Zn} 2, \mathrm{Zn} 2^{\prime}\right)$, resulting in a $\mu_{4}-\kappa \mathrm{N}: \kappa \mathrm{O}: \kappa \mathrm{N}: \kappa \mathrm{O}$ coordination mode of each bisureate ligand. The central tetrahedrally coordinated zinc atom $(\mathrm{Zn} 1)$ binds to four nitrogen atoms of two dianionic bis(ureate) ligands (2: N3, 3: N2/N7, 4: N2/N6), which are directly bonded to the linking alkyl chain. Each Zn1 atom of $\mathbf{2}-\mathbf{4}$ consequently adopts a $\kappa^{4}(N, N, N, N)$ coordination mode. The two bisureate ligands are further connected via two zinc atoms ( $\left.\mathrm{Zn} 2, \mathrm{Zn} 2{ }^{\prime}\right)$, which bind to one nitrogen and two oxygen atoms in a $\kappa^{3}(N, 0,0)$ coordination environment and to one additional alkyl group. The $\mathrm{Zn}$ atoms adopt slightly distorted tetrahedral coordination spheres and the bond angles deviate by about $\pm 15^{\circ}$ from the ideal tetrahedral angle.

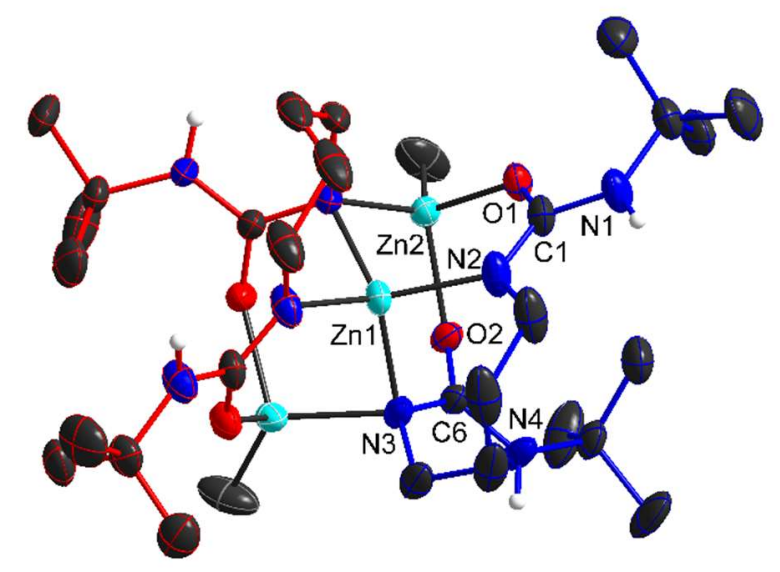

Figure 2. Solid state structure of $\mathbf{2}$. Non-H-atoms shown as thermal ellipsoids at $50 \%$ probability levels; Non $\mathrm{NH}$ hydrogen atoms omitted for clarity. The two ligands are highlighted in red and blue. The red one and the not labeled ZnR group are generated via 2-fold rotational symmetry.

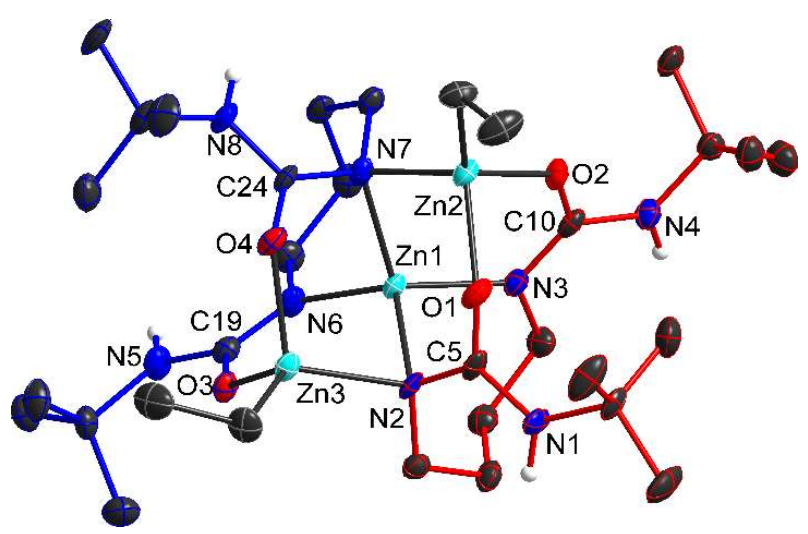

Figure 3. Solid state structure of $\mathbf{3}$. Non-H-atoms shown as thermal ellipsoids at $50 \%$ probability levels; Non NH hydrogen atoms omitted for clarity. The two ligands are highlighted in red and blue. 


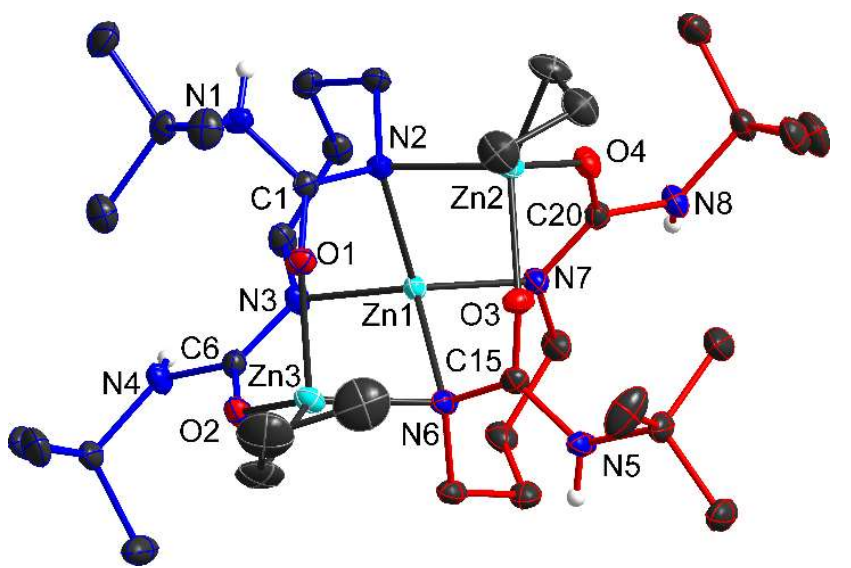

Figure 4. Solid state structure of 4 . Non-H-atoms shown as thermal ellipsoids at $50 \%$ probability levels; Non NH hydrogen atoms and second orientation of disordered parts omitted for clarity. The two ligands are highlighted in red and blue.

Table 1. Selected bond lengths $[\AA]$ of $\mathbf{1}$ - $\mathbf{4}$.

\begin{tabular}{|c|c|c|c|c|}
\hline & 1 & 2 & 3 & 4 \\
\hline Zn1-N2 & - & 1.9741(19) & $2.064(5)$ & $2.0715(12)$ \\
\hline Zn1-N3 & - & $2.0592(19)$ & $1.980(5)$ & $1.9779(12)$ \\
\hline Zn1-N6 & - & - & $1.977(5)$ & $2.0612(12)$ \\
\hline Zn1-N7 & - & - & $2.049(5)$ & $1.9810(13)$ \\
\hline $\mathrm{Zn} 2-\mathrm{C} 15 / 29$ & - & $1.964(3)$ & $1.977(6)$ & $1.9846(16)$ \\
\hline $\mathrm{Zn} 2 / 3-\mathrm{O} 1$ & - & $2.0154(16)$ & $2.020(4)$ & $2.0163(11)$ \\
\hline $\mathrm{Zn} 2 / 3-\mathrm{O} 2$ & - & $2.0259(15)$ & $2.001(4)$ & $2.0145(11)$ \\
\hline $\mathrm{Zn} 2 / 3-\mathrm{N} 3 / 6 / 7$ & - & $2.1145(19)$ & $2.119(5)$ & $2.1272(13)$ \\
\hline $\mathrm{Zn3}-\mathrm{C} 31 / 32$ & - & - & $1.972(6)$ & $2.007(8)$ \\
\hline $\mathrm{Zn} 2 / 3-\mathrm{O} 3$ & - & - & $2.011(4)$ & $2.0086(11)$ \\
\hline $\mathrm{Zn} 2 / 3-\mathrm{O} 4$ & - & - & $2.024(4)$ & $2.0117(11)$ \\
\hline $\mathrm{Zn} 2 / 3-\mathrm{N} 2$ & - & - & $2.102(5)$ & $2.1126(13)$ \\
\hline $\mathrm{N} 1-\mathrm{C} 1 / 5$ & $1.351(7)$ & $1.370(3)$ & $1.356(7)$ & $1.346(2)$ \\
\hline $\mathrm{N} 2-\mathrm{C} 1 / 5$ & $1.352(5)$ & $1.325(3)$ & $1.362(7)$ & $1.3679(19)$ \\
\hline $\mathrm{O} 1-\mathrm{C} 1 / 5$ & $1.236(4)$ & $1.272(3)$ & $1.264(8)$ & $1.2609(18)$ \\
\hline N3-C6/10 & $1.338(5)$ & - & $1.332(8)$ & $1.3209(19)$ \\
\hline N4-C6/10 & $1.346(5)$ & - & $1.368(8)$ & $1.3715(19)$ \\
\hline $\mathrm{O} 2-\mathrm{C} 6 / 10$ & $1.237(4)$ & - & $1.272(7)$ & $1.2755(18)$ \\
\hline
\end{tabular}

The $\mathrm{Zn}-\mathrm{N}$ bond lengths (Table 1) of the threefoldcoordinated nitrogen atoms $(2: \mathrm{N} 2,3: \mathrm{N} 3 / \mathrm{N} 6,4$ : N3/N7) to the central $\mathrm{Zn}$ atom $(\mathrm{Zn} 1)$ are about $8 \mathrm{pm}$ shorter compared to those of the fourfold-coordinated nitrogen atoms $(2: \mathrm{N} 3$, 3: N2/N7, 4: N2/N6), that adopt bridging positions between $\mathrm{Zn} 1$ and $\mathrm{Zn} 2 / \mathrm{Zn} 2 '$. The longest $\mathrm{Zn}-\mathrm{N}$ bonds are observed for the $\mathrm{Zn}$ atoms $(\mathrm{Zn} 2 / \mathrm{Zn} 3)$ to the bridging nitrogen atoms (2: N3, 3: N2/N7, 4: N2/N6), which are approx. 14 pm longer and within the typical range observed for rather dative $\mathrm{Zn}-\mathrm{N}$ bonds. As was expected, the C-O and $\mathrm{C}-\mathrm{N}$ bond length within the ligands was found to increase as a consequence of the coordination to the $\mathrm{Zn}$ atoms. The $\mathrm{Zn}-\mathrm{O}$ bond lengths are almost identical and range from 2.00 to $2.02 \AA$, as is typically observed for $\mathrm{Zn}-\mathrm{O}$ single bonds. Changes in the bond angles are neglectable (Table 2). The two terminal amide groups $(t-\mathrm{BuNH})$ of each bis(ureate) ligand are not involved in the coordination to the metal centers and one would expect the hydrogen atoms to engage in hydrogen bonding. However, since possible acceptors for hydrogen bonds are located in the center of the molecule or are sterically unavailable, no hydrogen bond formation is observed. Despite the different steric demand of the alkyl groups, the overall conformation of the molecules is in good approximation unaltered (see Figure 5).

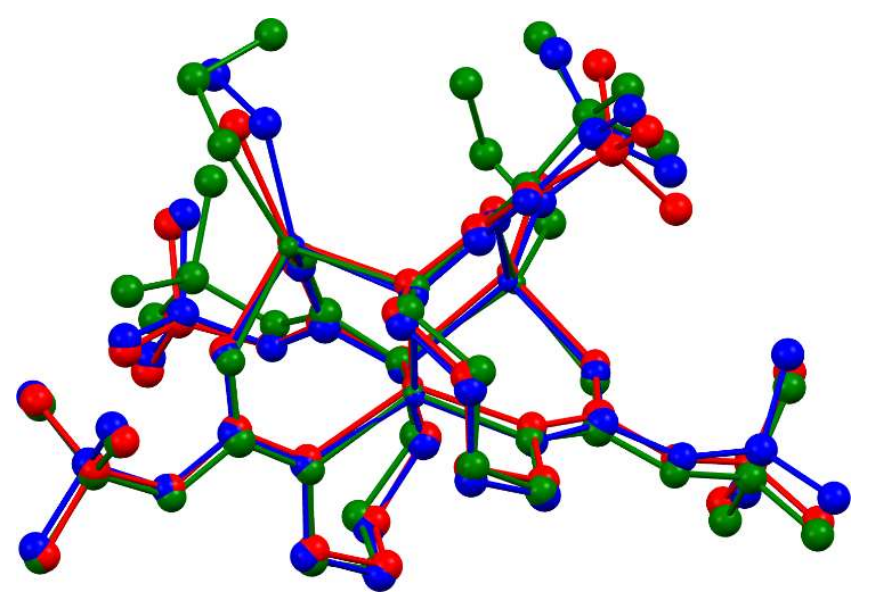

Figure 5. Overlay of the solid state structures of $\mathbf{2}$ (red) $\mathbf{3}$ (blue) and 4 (green).

Table 2. Selected bond angles $\left[{ }^{\circ}\right]$ of $\mathbf{1}$ - $\mathbf{4}$.

\begin{tabular}{lllll} 
& $\mathbf{1}$ & $\mathbf{2}$ & $\mathbf{3}$ & $\mathbf{4}$ \\
\hline $\mathrm{N} 2-\mathrm{Zn} 1-\mathrm{N} 3$ & - & $97.25(8)$ & $95.9(2)$ & $97.18(5)$ \\
$\mathrm{N} 2-Z n 1-\mathrm{N} 3$ 'N6 & - & $110.29(8)$ & $111.4(2)$ & $115.45(5)$ \\
$\mathrm{N} 2-Z n 1-\mathrm{N} 2$ 'N7 & - & $123.53(12)$ & $119.3(2)$ & $114.47(5)$ \\
$\mathrm{N} 3-\mathrm{Zn} 1-\mathrm{N} 3$ 'N6 & - & $119.99(11)$ & $125.2(2)$ & $113.71(5)$ \\
$\mathrm{N} 3-\mathrm{Zn} 1-\mathrm{N} 7$ & - & - & $109.5(2)$ & $119.35(5)$ \\
N6-Zn1-N7 & - & - & $97.4(2)$ & $97.88(5)$ \\
Zn1-N2/6-Zn3 & - & $90.79(7)$ & $90.85(18)$ & $92.48(5)$ \\
Zn1-N7/2-Zn2 & - & - & $92.3(2)$ & $91.91(5)$ \\
O1-Zn2/3-O2 & - & $98.94(6)$ & $97.24(18)$ & $103.00(4)$ \\
N1-C1/5-N2 & $114.2(3)$ & $119.8(2)$ & $121.0(6)$ & $121.15(13)$ \\
N1-C1/5-O1 & $123.6(4)$ & $117.5(2)$ & $118.6(5)$ & $118.54(14)$ \\
N2-C1/5-O1 & $122.1(4)$ & $122.7(2)$ & $120.4(5)$ & $120.30(13)$ \\
\hline
\end{tabular}

\section{Conclusions}

$\mathbf{1}$ is a powerful starting reagent for the synthesis of zinc complexes, which were obtained by alkane elimination of the corresponding zinc dialkyls $\mathrm{ZnR}_{2}$. Only the two N-H groups of each bis(urea) ligands, which are directly bonded to the linking alkyl chain, are metalated, resulting in the 
formation of the homotrimetallic zinc ureate complexes of the general type $\left[\mathrm{RZn}-1,4-(t-\mathrm{BuNHCON})_{2}-\mathrm{C}_{4} \mathrm{H}_{8}\right]_{2} \mathrm{Zn}(\mathrm{R}=$ Me 2, Et 3, n-Pr 4). These complexes each contain three tetrahedral coordinated zinc atoms, whose coordination environment differs: two $\mathrm{Zn}$ atoms are coordinated by one alkyl group as well as two oxygen and one nitrogen atom of the dianionic bis(ureate) ligand $\left(\mathrm{RZnNO}_{2}\right.$ coordination), whereas the central zinc atom is coordinated by four $\mathrm{N}$ atoms of two ureate ligands $\left(\mathrm{ZnN}_{4}\right.$ coordination). Further reactions of $\mathbf{1}$ and comparable derivatives with other transition metal and main group metal complexes will be performed in due course in order to prove their general applicability for the formation of metal complexes of the desired type. Moreover, the applicability of $\mathbf{2}-\mathbf{4}$ to serve as catalyst in the ring opening polymerization (ROP) of cyclic esters such as lactide is currently under investigation.

\section{Experimental Section}

All manipulations were performed in a glovebox under argon atmosphere or by using standard Schlenk techniques. Solvents were carefully dried with $\mathrm{Na} / \mathrm{K}$ and degassed prior to use. 1,4-[t$\mathrm{BuN}(\mathrm{H}) \mathrm{CONH}]_{2}-\mathrm{C}_{4} \mathrm{H}_{8} \mathbf{1}^{[21]}$ and $\mathrm{ZnR}_{2}\left(\mathrm{R}=\mathrm{Me}\right.$, Et, $n$ - $\left.\mathrm{Pr}_{2}\right)$ were prepared according to literature methods. ${ }^{[25]} \mathrm{NMR}$ spectra were recorded at $25{ }^{\circ} \mathrm{C}$ with a Bruker DMX 300 spectrometer $\left({ }^{1} \mathrm{H}: 300\right.$ $\left.\mathrm{MHz} ;{ }^{13} \mathrm{C}: 75 \mathrm{MHz}\right)$ and are referenced to internal $\mathrm{CDCl}_{3}\left({ }^{1} \mathrm{H}: \delta=\right.$ $\left.7.26 \mathrm{ppm} ;{ }^{13} \mathrm{C}: \delta=77.2 \mathrm{ppm}\right)$. IR spectra were recorded with an ALPHA-T FT-IR spectrometer equipped with a single-reflection ATR sampling module, which is placed in an argon filled glovebox. Melting points were measured in sealed capillaries. Elemental analyses were performed at the Elementaranalyse Labor of the University of Duisburg-Essen.

\section{General procedure for the synthesis of 2-4.}

A suspension of $1,4-(t-\mathrm{BuNHCONH})_{2}-\mathrm{C}_{4} \mathrm{H}_{8} \mathbf{1}(0.7 \mathrm{mmol}, 0.2 \mathrm{~g})$ in $10 \mathrm{~mL}$ of toluene was cooled to $-30{ }^{\circ} \mathrm{C}$ and $\mathrm{ZnR}_{2}(1.1 \mathrm{mmol} ; \mathrm{R}=$ Me $0.11 \mathrm{~g}$, Et $0.14 \mathrm{~g}, n$-Pr $0.16 \mathrm{~g}$ ) was slowly added via syringe. The resulting suspension was slowly warmed to ambient temperature, upon which a smooth gas evolution was observed, and stirred for additional $15 \mathrm{~h}$. The solvent and unreacted $\mathrm{ZnR}_{2}$ was removed in vacuo, yielding 2-4 as colorless crystalline powders. Single crystals of $\mathbf{2}$ were obtained after storage of a solution of $\mathbf{2}$ in fluorobenzene $/ \mathrm{Et}_{2} \mathrm{O}$ at $-30{ }^{\circ} \mathrm{C}$ for 5 days, whereas single crystals of 3 and 4 were obtained from solutions in toluene/ $/ \mathrm{Et}_{2} \mathrm{O}$ at $0{ }^{\circ} \mathrm{C}$ after $24 \mathrm{~h}$.

[MeZn-1,4-(t-BuNHCON)$\left.)_{2}-\mathbf{C}_{4} \mathbf{H}_{8}\right]_{2} Z \mathbf{Z n}$ 2. Yield: $0.52 \mathrm{~g}$ (93\%). Mp.: $220^{\circ} \mathrm{C}$ (dec.). Elemental analysis calcd (\%) for $\mathrm{C}_{30} \mathrm{H}_{62} \mathrm{~N}_{8} \mathrm{O}_{4} \mathrm{Zn}_{3}$ (795.09 g/mol): C, 44.80 (45.32); H, 7.99 (7.86); N, 13.95 (14.09) \%. ${ }^{1} \mathrm{H}$ NMR (300 MHz, $\left.\mathrm{CDCl}_{3}, 25^{\circ} \mathrm{C}\right): \delta-1.03$ (s, 6 $\mathrm{H}, \mathrm{ZnMe}), 1.27$ (s, $\left.20 \mathrm{H}, \mathrm{CMe}_{3}, \mathrm{CH}_{2}\right), 1.29$ (s, $20 \mathrm{H}, \mathrm{CMe}_{3}, \mathrm{CH}_{2}$ ), $1.54\left(\mathrm{~m}, 2 \mathrm{H}, \mathrm{CH}_{2}\right), 1.72\left(\mathrm{t},{ }^{3} \mathrm{~J}_{\mathrm{HH}}=12.55 \mathrm{~Hz}, 2 \mathrm{H}, \mathrm{CH}_{2}\right), 1.92(\mathrm{t}$, $\left.{ }^{3} \mathrm{~J}_{\mathrm{HH}}=12.80 \mathrm{~Hz}, 2 \mathrm{H}, \mathrm{CH}_{2}\right), 2.57\left(\mathrm{t},{ }^{3} \mathrm{~J}_{\mathrm{HH}}=12.04 \mathrm{~Hz}, 2 \mathrm{H}, \mathrm{CH}_{2}\right)$, 2.94-3.02 (m, $\left.6 \mathrm{H}, \mathrm{CH}_{2}\right), 3.83$ (s, $\left.2 \mathrm{H}, \mathrm{NH}\right), 4.66(\mathrm{~s}, 2 \mathrm{H}, \mathrm{NH}) .{ }^{13} \mathrm{C}$ NMR (75 MHz, $\left.\mathrm{CDCl}_{3}, 25^{\circ} \mathrm{C}\right): \delta-20.5(\mathrm{ZnMe}), 27.3\left(\mathrm{CH}_{2}\right), 29.7$ $\left(\mathrm{CH}_{2}\right), 29.8\left(\mathrm{CH}_{2}\right), 30.0\left(\mathrm{CH}_{2}\right), 47.8\left(\mathrm{NCMe}_{3}\right), 47.9\left(\mathrm{NCMe}_{3}\right), 50.4$ $\left(\mathrm{NCMe}_{3}\right), 51.2\left(\mathrm{NCMe}_{3}\right), 162.0(\mathrm{CO}), 166.6(\mathrm{NCN}) . \mathrm{IR}\left(\mathrm{v}, \mathrm{cm}^{-1}\right)$ : $3365,2963,2937,2856,1632,1558,1525,1451,1360,1327,1277$, 1242, 1214, 1193, 1152, 1051, 972, 933, 786, 774, 749, 631, 453, $419 \mathrm{~cm}^{-1}$.

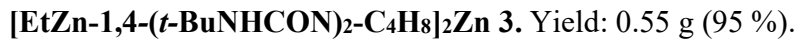

Mp.: $>220{ }^{\circ} \mathrm{C}$ (dec.). Elemental analysis calcd (\%) for $\mathrm{C}_{32} \mathrm{H}_{66} \mathrm{~N}_{8} \mathrm{O}_{4} \mathrm{Zn}_{3}(823.14 \mathrm{~g} / \mathrm{mol}): \mathrm{C}, 46.50$ (46.69); H, 8.01 (8.08); N, 13.57 (13.61) \%. ${ }^{1} \mathrm{H}$ NMR $\left(300 \mathrm{MHz}, \mathrm{CDCl}_{3}, 25{ }^{\circ} \mathrm{C}\right): \delta-0.03$ (quart, ${ }^{3} \mathrm{~J}_{\mathrm{HH}}=8.10 \mathrm{~Hz}, 4 \mathrm{H}, \mathrm{ZnCH}_{2} \mathrm{CH}_{3}$ ), $1.20\left(\mathrm{t},{ }^{3} \mathrm{~J}_{\mathrm{HH}}=8.11 \mathrm{~Hz}, 6\right.$
$\left.\mathrm{H}, \mathrm{ZnCH}_{2} \mathrm{CH}_{3}\right), 1.27$ (s, $\left.18 \mathrm{H}, \mathrm{CMe}_{3}\right), 1.30$ (s, $\left.18 \mathrm{H}, \mathrm{CMe}_{3}\right), 1.35$ $\left(\mathrm{m}, 4 \mathrm{H}, \mathrm{CH}_{2}\right), 1.51\left(\mathrm{~m}, 2 \mathrm{H}, \mathrm{CH}_{2}\right), 1.70\left(\mathrm{t},{ }^{3} \mathrm{~J}_{\mathrm{HH}}=12.59 \mathrm{~Hz}, 2 \mathrm{H}\right.$, $\left.\mathrm{CH}_{2}\right), 1.90\left(\mathrm{t},{ }^{3} \mathrm{~J}_{\mathrm{HH}}=12.80 \mathrm{~Hz}, 2 \mathrm{H}, \mathrm{CH}_{2}\right), 2.56\left(\mathrm{t},{ }^{3} \mathrm{~J}_{\mathrm{HH}}=12.14 \mathrm{~Hz}\right.$, $\left.2 \mathrm{H}, \mathrm{CH}_{2}\right), 2.98-3.02\left(\mathrm{~m}, 6 \mathrm{H}, \mathrm{CH}_{2}\right), 3.82(\mathrm{~s}, 2 \mathrm{H}, \mathrm{NH}), 4.66(\mathrm{~s}, 2 \mathrm{H}$, $\mathrm{NH}) .{ }^{13} \mathrm{C} \mathrm{NMR}\left(75 \mathrm{MHz}, \mathrm{CDCl}_{3}, 25{ }^{\circ} \mathrm{C}\right): \delta-4.6\left(\mathrm{ZnCH}_{2} \mathrm{CH}_{3}\right), 13.6$ $\left(\mathrm{ZnCH}_{2} \mathrm{CH}_{3}\right), 27.3\left(\mathrm{CH}_{2}\right), 29.6\left(\mathrm{CH}_{2}\right), 29.8\left(\mathrm{CH}_{2}\right), 30.0\left(\mathrm{CH}_{2}\right), 47.8$ (NCMe 3$), 48.0$ (NCMe3), 50.4 ( $\left.\mathrm{NCMe}_{3}\right), 51.1\left(\mathrm{NCMe}_{3}\right), 162.0$ (CO), $166.8(\mathrm{NCN})$. IR $\left(v, \mathrm{~cm}^{-1}\right): 3444,2996,2963,2929,2835$, 2803, 1581, 1514, 1486, 1441, 1392, 1355, 1336, 1312, 1271, 1239, $1211,1138,1119,1078,1056,1044,1020,983,932,901,831,797$, $645,598,578,525,434 \mathrm{~cm}^{-1}$.

[n-PrZn-1,4-(t-BuNHCON$\left.)_{2}-\mathbf{C}_{4} \mathbf{H}_{8}\right]_{2} \mathbf{Z n} 4$. Yield: $0.56 \mathrm{~g}(95 \%)$. Mp.: $>220{ }^{\circ} \mathrm{C}$ (dec.). Elemental analysis calcd (\%) for $\mathrm{C}_{34} \mathrm{H}_{68} \mathrm{~N}_{8} \mathrm{O}_{4} \mathrm{Zn}_{3}$ (849.18 g/mol): C, 48.03 (48.09); H, 8.04 (8.07); N, 13.15 (13.20) \%. ${ }^{1} \mathrm{H}$ NMR (300 MHz, $\left.\mathrm{CDCl}_{3}, 25^{\circ} \mathrm{C}\right): \delta 0.09(\mathrm{t}$, $\left.{ }^{3} \mathrm{~J}_{\mathrm{HH}}=7.34 \mathrm{~Hz}, 4 \mathrm{H}, \mathrm{ZnCH} \mathrm{CH}_{2} \mathrm{CH}_{3}\right), 0.94\left(\mathrm{t},{ }^{3} \mathrm{~J}_{\mathrm{HH}}=7.21 \mathrm{~Hz}, 6 \mathrm{H}\right.$, $\mathrm{ZnCH}_{2} \mathrm{CH}_{2} \mathrm{CH}_{3}$ ), 1.27 (s, $18 \mathrm{H}, \mathrm{CMe}$ ), 1.29 (s, $18 \mathrm{H}, \mathrm{CMe}$ ), 1.30$1.33\left(\mathrm{~m}, 4 \mathrm{H}, \mathrm{CH}_{2}\right), 1.51\left(\mathrm{~m}, 2 \mathrm{H}, \mathrm{CH}_{2}\right), 1.57$ (sext, ${ }^{3} \mathrm{~J}_{\mathrm{HH}}=7.34 \mathrm{~Hz}$, $\left.4 \mathrm{H}, \mathrm{ZnCH}_{2} \mathrm{CH}_{2} \mathrm{CH}_{3}, 2 \mathrm{H}, \mathrm{CH}_{2}\right), 1.71\left(\mathrm{t},{ }^{3} \mathrm{~J}_{\mathrm{HH}}=12.55 \mathrm{~Hz}, 2 \mathrm{H}\right.$, $\left.\mathrm{CH}_{2}\right), 1.90\left(\mathrm{t},{ }^{3} \mathrm{~J}_{\mathrm{HH}}=12.80 \mathrm{~Hz}, 2 \mathrm{H}, \mathrm{CH}_{2}\right), 2.56\left(\mathrm{t},{ }^{3} \mathrm{~J}_{\mathrm{HH}}=11.98 \mathrm{~Hz}\right.$, $\left.2 \mathrm{H}, \mathrm{CH}_{2}\right), 2.95-3.05\left(\mathrm{~m}, 6 \mathrm{H}, \mathrm{CH}_{2}\right), 3.82$ (s, $\left.2 \mathrm{H}, \mathrm{NH}\right), 4.65$ (s, $2 \mathrm{H}$, $\mathrm{NH}) .{ }^{13} \mathrm{C} \mathrm{NMR}\left(75 \mathrm{MHz}, \mathrm{CDCl}_{3}, 25{ }^{\circ} \mathrm{C}\right): \delta 7.8\left(\mathrm{ZnCH}_{2} \mathrm{CH}_{2} \mathrm{CH}_{3}\right)$, $21.1\left(\mathrm{ZnCH}_{2} \mathrm{CH}_{2} \mathrm{CH}_{3}\right), 22.4\left(\mathrm{CH}_{3}\right), 27.3\left(\mathrm{CH}_{2}\right), 29.4\left(\mathrm{CH}_{2}\right), 29.6$ $\left(\mathrm{CH}_{2}\right), 30.0\left(\mathrm{CH}_{2}\right), 47.8(\mathrm{NCMe}), 48.0(\mathrm{NCMe}), 50.3\left(\mathrm{NCMe}_{3}\right)$, $51.1\left(\mathrm{NCMe}_{3}\right), 162.0(\mathrm{CO}), 166.5(\mathrm{NCN}) . \mathrm{IR}\left(\mathrm{v}, \mathrm{cm}^{-1}\right)$ : 3442, 2963, 2930, 2868, 2811, 1582, 1513, 1486, 1442, 1394, 1362, 1309, 1260, $1243,1212,1199,1178,1119,933,865,796,763,699,657,643$, $531,502,433,384 \mathrm{~cm}^{-1}$.

Single crystal X-ray diffraction. Crystallographic data of 1-4, which were collected on a Bruker AXS D8 Kappa diffractometer with APEX2 detector (MoK $\alpha$ radiation, $\lambda=0.71073 \AA$ ) at 100(1) $\mathrm{K}(\mathbf{3}, \mathbf{4})$ and $180(1) \mathrm{K}(\mathbf{1}, \mathbf{2})$, are summarized in Table S1 (SI). The solid-state structures of of 1-4 are shown in Figures 1-4, bond lengths and angles of of 1-4 are summarized in Table 1. The structures were solved by Direct Methods (SHELXS-97) and refined anisotropically by full-matrix least-squares on $\mathrm{F}^{2}$ (SHELXL-2014). ${ }^{[26,27]}$ Absorption corrections were performed semi-empirically from equivalent reflections on basis of multiscans (Bruker AXS APEX2). Hydrogen atoms were refined using a riding model or rigid methyl groups. In $\mathbf{1}$ a part of one independent molecule is disordered over two positions. To avoid correlations in the final refinement the occupancies were fixed at 0.2 and 0.8 . In 3 the model was refined as pseudo-merohedrally twinned by twofold rotation about $a$. The metrics of the unit cell suggests that it might be isostructural to $\mathbf{2}$ and indeed it may be solved in monoclinic $P 2 / n$. The systematic extinctions for an $n$ glide-plane symmetry are not full-filled and $R_{\text {int }}$ is $\sim 24 \%$. The final $R 1$ and $w R 2$ values of the model are $30 \%$ and $67 \%$ respectively. However, a closer inspection of the reciprocal suggests that several highly overlapping twin components may be present. Any attempts to separate them failed. Thus the triclinic model is the best available. It should be noted that quantitative results may be unreliable. In 4 the NH hydrogen atoms could be identified in the difference Fourier synthesis and were refined freely with its NH distance restrained to $0.87 \AA$ (DFIX). One of the propyl groups was disordered over two positions. RIGU restraints were applied to the atomic displacement parameters of the corresponding atoms. The crystallographic data of 1-4 (excluding structure factors) have been deposited with the Cambridge Crystallographic Data Centre as supplementary publication nos. CCDC-1572048 (1), CCDC1572049 (2), CCDC-1572050 (3) and CCDC-1572051 (4). Copies of the data can be obtained free of charge on application to CCDC, 
12 Union Road, Cambridge, CB21EZ (fax: (+44) 1223/336033; email: deposit@ccdc.cam-ak.uk).

Supporting Information (see footnote on the first page of this article): A CIF file giving X-ray crystallographic data of 1-4, spectroscopic details $\left({ }^{1} \mathrm{H},{ }^{13} \mathrm{C}\right.$ NMR; IR) and crystallographic details of 1-4.

\section{Acknowledgement}

Stephan Schulz gratefully acknowledges financial support by the University of Duisburg-Essen.

[1] S. A. Ryken, P. R. Payne, L. L. Schafer, in Ligand Design in Metal Chemistry: Reactivity and Catalysis, 1st ed., chapter 13, Tight Bite Angle N,O-Chelates. Amidates, Ureates and Beyond, Eds. M. Stradiotto, R. J. Lundgren, John Wiley \& Sons, Ltd. 2016.

[2] F. Wöhler, Ann. Physik 1828, 12, 253-256.

[3] a) A. S. Megahed, O. B. Ibrahim, A. M. A. Adam, M. M. AL-Majthoub, Res. J. Pharm. Biol. Chem. Sci. 2014, 5, 960969; b) I. Persson, K. Lyczko, D. Lundberg, L. Eriksson, A. Placzek, Inorg. Chem. 2011, 50, 1058-1072; c) E. Diamantopoulou, G. S. Papaefstathiou, A. Terzis, C. P. Raptopoulou, H. O. Desseyn, S. P. Perlepes, Polyhedron 2003, 22, 825-835; d) R. Keuleers, G.S. Papaefstathiou, C. P. Raptopoulou, S. P. Perlepes, H. O. Desseyn, J. Mol Struct. 2000, 525, 173-183; e) T. Theophanides, P. D. Harvey, Coord. Chem. Rev. 1987, 76, 237-264; f) A. Bittner, D. Maennig, H. Nöth, Z. Naturforsch. 1986, 41B, 587-591; g) C. Airoldi, A. P. Chagas, F. P. Assuncao, Dalton Trans. 1980, 1823-1826.

[4] a) O. B. Ibrahim, $A d v$. Appl. Sci. Res. 2012, 3, 3522-3539; b) L. Drakopoulou, C. P. Raptopoulou, A. Terzis, G. S. Papaefstathiou, Bioinorg. Chem. Appl. 2010, 618202.

[5] M. Sugimura, Y. Kameyama, T. Hashimoto, T. Kobayashi, S. Muramatsu. Chem. Abs. 1990, 112, 63.

[6] See for instance: a) I. Carreira-Barral, T. Rodriguez-Blas, C. Platas-Iglesias, A. de Blas, D. Esteban-Gomez, Inorg. Chem. 2014, 53, 2554-2568; b) G. Baggi, M. Boiocchi, C. Ciarrocchi, L. Fabbrizzi, Inorg. Chem. 2013, 52, 5273-5283; c) V. Amendola, L. Fabbrizzi, L. Mosca, Chem. Soc. Rev. 2010, 39, 3889-3915; d) C. M. G. dos Santos, T. McCabe, G. W. Watson, P. Kruger, T. Gunnlaugsson, J. Org. Chem. 2008 73, 9235-9244; e) V. Amendola, M. Bonizzoni, D. EstebanGomez, L. Fabbrizzi, M. Licchelli, F. Sancenon, A. Taglietti, Coord. Chem. Rev. 2006, 250, 1451-1470; f) M. Boiocchi, L. Del Boca, D. Esteban-Gómez, L. Fabbrizzi, M. Licchelli, E. Monzani, Chem. Eur. J. 2005, 11, 3097-3104.

[7] a) C. M. Lombardo, G. W. Collie, K. Pulka-Ziach, F. Rosu, V. Gabelica, C. D. Mackereth, G. Guichard, J. Am. Chem. Soc. 2016, 138, 10522-10530; b) Romina Wechsel, J. Raftery, D. Cavagnat, G. Guichard, J. Clayden, Angew. Chem. Int. Ed. 2016, 55, 9657-9661, Angew. Chem. 2016, 128, 9809-9813.

[8] a) P. S. Gentile, P. Carfagno, S. Haddad, L. Campisi, Inorg. Chim. Acta 1972, 6, 296-298; b) D. S. Sagatys, R. C. Bott, G. Smith, K. A. Byriel, C. H. L. Kennard, Polyhedron, 1992, 11, 49-52; K. Lewinski, J. Sliwinski, L. Lebioda, Inorg. Chem. 1983, 22, 2339-2342; d) L. Lebioda, Acta Crystallogr. 1980 B36, 271-275.

[9] Cambridge Structural Database, Version 5.37, see also: F. H. Allen, Acta Cryst. 2002, B58, 380-388.

[10] a) S. V. Kryatov, A. Y. Nazarenko, P. D. Robinson, E. V. Rybak-Akimova, Chem. Commun. 2000, 11, 921-922; b) F Meyer, M. Konrad, E. Kaifer, Eur. J. Inorg. Chem. 1999 1851-1854; c) F. Meyer, H. Pritzkow, Chem. Commun. 1998 1555-1556; d) D. C. Leitch, J. D. Beard, R. K. Thomson, W. A. Wright, B. O. Patrick, L. L. Schafer, Eur. J. Inorg. Chem. 2009, 2691-2701.
[11] H. Sawinski, R. Dronskowski, Z. Anorg. Allg. Chem. 2014 640, 846-850

[12] D. C. Leitch, L. L. Schafer, Organometallics 2010, 29, 51625172.

[13] a) M. A. El-Ghamry, A. A. Saleh, S. M. E. Khalil, A. A Mohammed, Spectrochim. Acta A 2013, 110, 205-216; b) D. D. Díaz, S. S. Gupta, J. Kuzelka, M. Cymborowski, M. Sabat, M. G. Finn, Eur. J. Inorg. Chem. 2006, 4489-4493.

[14] a) J. M. P. Lauzon, L. L. Schafer, Z. Anorg. Allg. Chem. 2015 , 641, 128-135; b) D. C. Leitch, P. R. Payne, C. R. Dunbar, L. L. Schafer, J. Am. Chem. Soc. 2009, 131, 18246-18247.

[15] D. C. Leitch, R. H. Platel, L. L. Schafer, J. Am. Chem. Soc. 2011, 133, 15453-15463.

[16] See for instance: Homo- and Heterobimetallic Complexes in Catalysis - Cooperative Catalysis, Top. Organomet. Chem. Ed. P. Kalck, Springer International Publishing Switzerland, 2016.

[17] a) S. Schulz, T. Eisenmann, S. Schmidt, D. Bläser, U. Westphal, R. Boese, Chem. Commun. 2010, 46, 7226-7228, b) S. Schulz, T. Eisenmann, D. Schuchmann, M. Bolte, M. Kirchner, R. Boese, J. Spielmann, S. Harder, Z. Naturforsch. 2009, 64b, 1397-1400; c) S. Schulz, T. Eisenmann, D. Bläser, R. Boese, Z. Anorg. Allg. Chem. 2009, 635, 995-1000; d) S. Schulz, T. Eisenmann, U. Westphal, S. Schmidt, U. Flörke, $Z$. Anorg. Allg. Chem. 2009, 635, 216-220.

[18] a) S. Schmidt, S. Schulz, D. Bläser, C. Wölper, Main Group Metal Chem. 2012, 35, 35-40; b) S. Schulz, S. Schmidt, D. Bläser, C. Wölper, Z. Anorg. Allg. Chem. 2012, 638, 17051710; c) S. Schmidt, B. Gutschank, S. Schulz, D. Bläser, R. Boese, C. Wölper, Eur. J. Inorg. Chem. 2011, 4464-4470; d) S. Schmidt, R. Schäper, S. Schulz, D. Bläser, C. Wölper, Organometallics 2011, 30, 1073-1078; e) S. Schmidt, S. Schulz, D. Bläser, R. Boese, M. Bolte, Organometallics 2010, 29, 6097-6103; f) B. Gutschank, S. Schulz, D. Bläser, R. Boese, C. Wölper, Organometallics 2010, 29, 6133-6136; g) B. Gutschank, S. Schulz, U. Westphal, D. Bläser, R. Boese, Organometallics 2010, 29, 2093-2097; h) M. Münch, U. Flörke, M. Bolte, S. Schulz, D. Gudat, Angew. Chem. 2008 120, 1535-1537; Angew. Chem. Int. Ed. 2008, 47, 1512-1514.

[19] S. Schulz, R. Schäper, D. Bläser, C. Wölper, Z. Anorg. Allg. Chem. 2012, 638, 2102-2105.

[20] a) C. Scheiper, S. Schulz, C. Wölper, D. Bläser, J. Roll, Z Anorg. Allg. Chem. 2013, 639, 1153-1159, b) C. Scheiper, D. Dittrich, C. Wölper, D. Bläser, J. Roll, S. Schulz, Eur. J. Inorg. Chem. 2014, 2230-2240.

[21] S. Schulz, M. Bayram, D. Bläser, C. Wölper, Organometallics 2014, 33, 2080-2087.

[22] W. Zhang, L. R. Sita, Adv.Synth. Catal. 2008, 350, 439-447.

[23] P. Vaughan, J. Donohue, Acta Crystallogr. 1952, 5, 530-535.

[24] L. Pauling, L. O. Brockway, J. Y. Beach, J. Am. Chem. Soc. 1935, 5, 2705-2709.

[25] M. Nanjo, T. Oda, K. Mochida, J. Organometal. Chem. 2003, 672, 100-108.

[26] G. M. Sheldrick, Acta Crystallogr. Sect. A 1990, 46, 467-473.

[27] a) G. M. Sheldrick, SHELXL-2014, Program for the Refinement of Crystal Structures University of Göttingen, Göttingen (Germany) 2014. (see also: G. M. Sheldrick, Acta Crystallogr. 2008, A64, 112-122.); b) shelXle, A Qt GUI for SHELXL, C. B. Hübschle, G. M. Sheldrick, B. Dittrich, J. Appl. Cryst. 2011, 44, 1281-1284.

Received: ((will be filled in by the editorial staff)) Published online: ((will be filled in by the editorial staff)) 


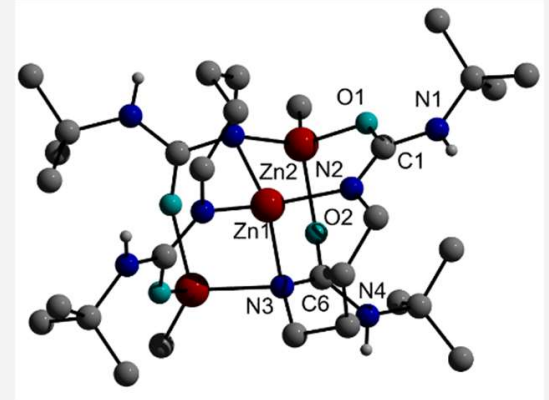

Melike Bayram, Christoph Wölper and Stephan Schulz* Page No. - Page No.

Synthesis and X-ray crystal structures of homotrimetallic Zinc Bisureate Complexes 


\section{DuEPublico}

Duisburg-Essen Publications online

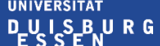

offen im Denken

This text is made available via DuEPublico, the institutional repository of the University of Duisburg-Essen. This version may eventually differ from another version distributed by a commercial publisher.

DOI: $\quad 10.1002 /$ zaac. 201700350

URN: urn:nbn:de:hbz:464-20201215-102335-6

This is the peer reviewed version of the following article: Z. Anorg. Allg . Chem. 2018, $644,1705-1710$, which has been published in final form at:

https://doi.org/10.1002/zaac.201700350

All rights reserved. 